\title{
Comparative investigation into Pre-COVID-19 and Post-COVID-19 lockdown Water Demand in selected schools in Osun State, Nigeria
}

\author{
Ogunbode Timothy O \\ Environmental Management Programme \\ College of Agriculture, Enginnering and Science, \\ Bowen University, Iwo, Nigeria \\ Email: timothy.ogunbode@bowen.edu.ng
}

\begin{abstract}
The prevalence of corona virus and the novel COVID-19 disease in the entire globe has exacerbated different impact on socioeconomic spectrum in the world, including water use pattern. Thus a research was conducted to examine the comparative use of water during pre- and post-COVID-19 lockdown pattern among post-primary schools in Iwo, Osun State, Nigeria. A survey was conducted among fifteen schools which were randomly selected, but with eight public and seven private schools for the investigation. Both descriptive and inferential statistical techniques were used in data analysis. The results revealed that the major source of water to the schools investigated is ground water which is obtained through hand-dug wells and boreholes. It was further discovered that there was increase in water use during post-COVID-19 lockdown era as a result of the directive by the government that clean water should be provided for hand-washing by all schools regardless of the owner to curtail the spread of COVID-19 disease in the country. One sample t-test also revealed that there was a significant difference in water use at $(\mathrm{p}<0.01)$ level. It is recommended that the government and other stakeholders in water sector to ensure that all-time and non-seasonal dependent source of water be provided rather than ground water source which is susceptible to variations in water yields from seasonal variations. This will enable continuous clean water supply, for all purposes, including COVID-19 protocols.
\end{abstract}

Key word: Pre-COVID-19; Post-COVID-19; Secondary Schools; Water Demand; Groundwater; Nigeria

\section{Introduction}

The prevalence of corona virus and the novel COVID-19 disease in the entire globe has exacerbated different impact on socioeconomic spectrum in the world, including water use pattern. For instance, it has become compulsory for every corporate organizations and establishments to ensure that unrestricted access to clean water is provided for everyone for regular hand washing as a measure to checkmate the spread of the virus. It has been recommended that everyone must take as a routine exercise to wash their hands almost every thirty minutes in order to get rid of the spread of the virus (WHO, 2020). In view of this directive, even as many educational institutions and other public establishments come to live after the lockdown necessitated by the spread of $\mathrm{C}-19$, clean water becomes a required item for their operations. Though there are other measures put in place and also recommended to curtail the spread of the highly contagious disease apart from hand washing with clean water such as the use of hand sanitizer, social distancing and the use of nose mask and shades, hand washing has been listed as the cheapest, affordable and accessible to ordinary man on the globe, Nigeria inclusive.

The use of hand sanitizer could be expensive and hard to be acquired by average Nigerians by virtue of the level of poverty and battered economy. Social distancing may be difficult to sustain in the context of Africa because of the low level of development. Africa is characterized with features such as periodic markets, religious gatherings, and commercial transportation among others. All these media are 'good' avenues and fora for the spread of the virus. Though, the use of face masks and shades could be relatively 
cheaper than the use of sanitizer, its use is bedeviled with lack of personal hygiene, and even if care is not taken the virus could be contracted through the use of masks if not well taken care of by regular washing and keeping in a safe place which should be free from the virus. The best and the cheapest option at this stage is hand washing with soap and clean water. However, the combination of all these measures have been recommended. Thus, availability of and accessibility to clean water becomes desirable. Already, it has been established that an unhindered access to potable water is a necessity for human life survival on the surface of the earth, thus it formed one of the 2015 millennium development goals (MDGs) and currently on the Sustainable Development Goals (SDGs). Ancient and modern civilization trends have shown that proximity to water source has a lot to contribute to human livelihood. The growth and development of most ancient settlements could be traced to the presence of adequate and access to water. For instance, the development of Egypt enjoys the gesture of River Nile and many more. On the other hand, investigations carried out have shown that the survival of man is partly and significantly dependent on the access to water in the areas of agriculture, industrial growth and development and domestic uses. However, with the prevalence of COVID-19 pandemic globally the per capita water usage is expected to become more than it used to be. It has become almost a daily lifestyle and entry license for every home and institutions, corporate and otherwise that at the entrance, adequate clean water and soap or sanitizer are provided for everyone entering to access for hand washing. This will take care of the hand washing required to subdue the spread of the disease at local, national and global levels. Nunes et al (2019), investigated into water use indicators in public schools in Recife, Brazil and found that there are remarkable variations in the consumption indicators (CI) based on the school typologies: $11.5+2.0 \mathrm{~L} /$ student/day for regular schools, $13.5+3.5 \mathrm{~L} /$ student/day for extended period schools, $22.0+6.0 \mathrm{~L} /$ student/day in full period schools and $18.5+6.5 \mathrm{~L} / \mathrm{student} /$ day in technical schools. Based on their findings, it was recommended that schools with a limited supply of potable water can be identified so that specific steps can be taken to achieve a sustainable water use in the school environment. Similarly, Egbinola and Amanambu (2015) found that $77 \%$ of the schools surveyed did not have wash hand basins while $76 \%$ use pit toilet, the situation indicating poor access to potable water in their study area. Egbinola and Amanambu therefore recommended that appropriate authorities/stakeholders should take it as a priority investing in the provision of clean water in the school environment. Borreti (2020) had already revealed that the outbreak of COVID-19 will compound the problem of water scarcity in Africa which had already been a challenge for other reasons, notably, increase in the population. Thus, more pressure will be put on water supply by the outbreak which was already scarce in most African nations (Ogunbode et al, 2020)

This research has been carried out to compare pre- and post-COVID-19 water demand in a selected postprimary schools in Iwo, Osun State, Nigeria in order to ascertain pattern of water demand in relation to the its availability. Specific objectives are two folds: First, to assess the sources and quantities of water used in the public and private secondary schools during the pre-COVID-19 and post-COVID-19 era and secondly, to evaluate the impact of COVID-19 on water demand.

\section{Methodology}

\section{Study Area}

This research was carried out in Iwo Township (Figure 1). Iwo, located in Osun State in the southwestern Nigeria, has an area of $245 \mathrm{~km}^{2}$ with a population of 191,348 according to 2006 population census. It is located on the coordinate axis of $7^{0} 38^{\prime} \mathrm{N}$ and $4^{0} 11^{\prime} \mathrm{E}$. The prevailing climatic condition is tropical with about eight months of rainfall (March to October) and about four months of dry season (November to February). Ogunbode (2015) discovered that annual rainfall in most tropical wet climate regions ranges between $1000 \mathrm{~mm}$ and $2000 \mathrm{~mm}$ with double maxima in July and September. Iwo habitants are predominantly farmers with high dependence on rainfall for agricultural practices. Apart from this the 
dominant vegetation is tropical forest comprising hardwoods such as obeche, walnuts, acacia, eucalyptus among others. In addition, the dominant agricultural practice is growing of permanent and annual crops such as cocoa, kolanut, oil palm, yam, maize and so on. However, the dry period in the year is often dominated with farming in the wetlands and along some river banks. Aiba Water Reservoir located within Government Forest Reservation Area in Iwo forms one of the sources of potable water for home use in the area. However, as a result of unreliable and erratic supply from this Water Works and, in view of the susceptibility of the surface to pollutants, inhabitants have resorted to the exploitation of subsurface sources.

In addition, Iwo has attracted both private primary and secondary schools established by various proprietors, corporate/religious organisations and private individuals. These private schools are in addition to the government-owned schools located in the community. Iwo is located within the tropical climate which is characterized by seasonal rainfall and mean monthly temperature of about $280 \mathrm{C}$. Iwo township was part of the lockdown which was instituted to curb the continuous spread of COVID-19 disease in 2020, the event that brought the socioeconomic activities to a standstill for between seven and ten months of the year.

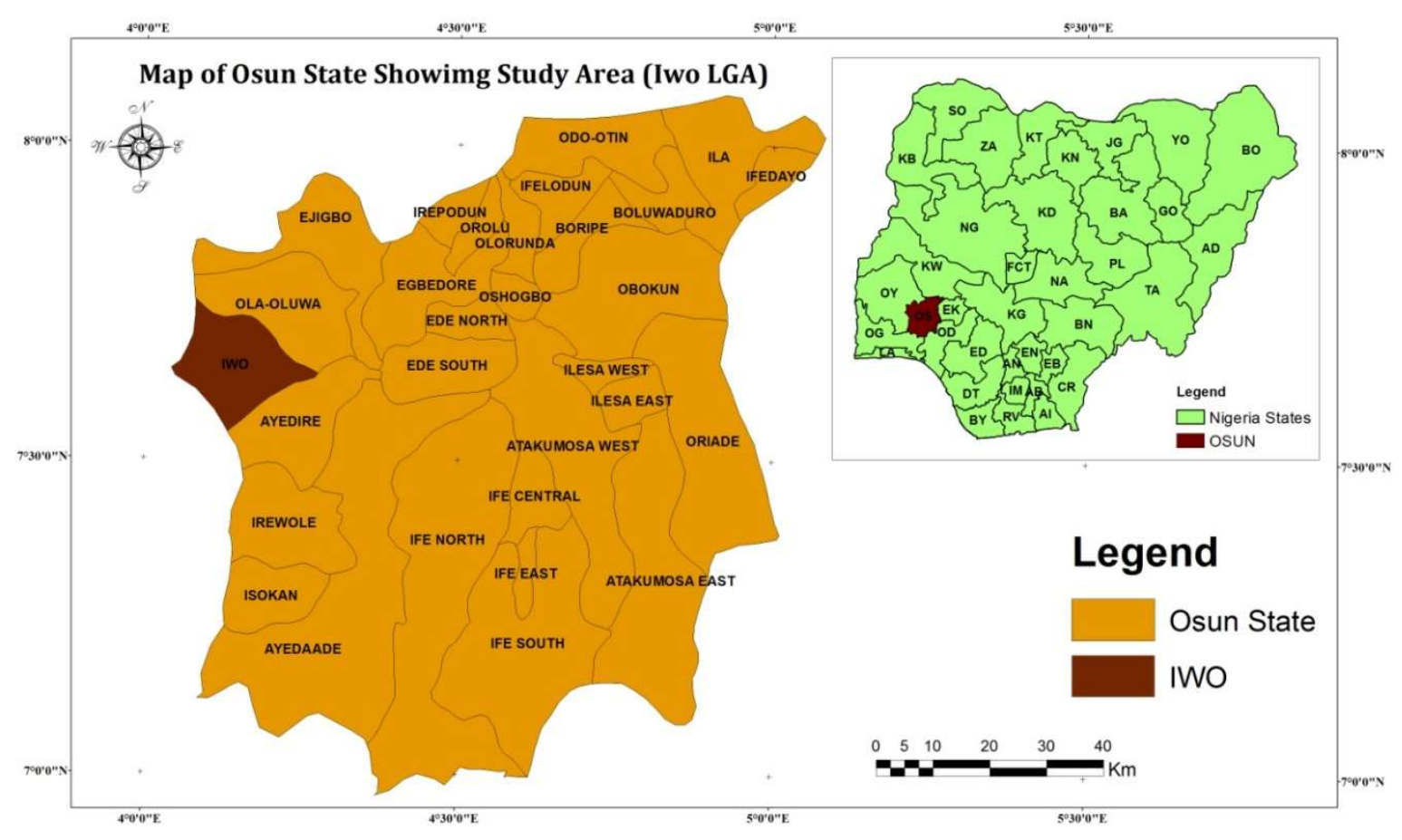

Iwo is underlain by Precambrian Basement Complex comprising mostly gneiss, granite, schist, undifferentiated met-sediment rocks and overburden that are comprised mainly of clay, sand and silt soils. This composition is neither porous nor permeable except where they are deeply weathered or along the lines of weakness. Also, Iwo is drained majorly by rivers such as Oba and Aiba River and other smaller streams.

\section{Data Collection}

Eight (8) public and seven (7) private schools were purposely selected within the township of Iwo to assess the pattern of water use during the post-COVID-19 lockdown Fifteen secondary schools were 
randomly selected in all. Each head of the selected schools were given the questionnaire to complete, who may authorize any of staff to do it on his/her behalf for their respective schools.

\section{Data Analysis}

Statistical methods to include descriptive Statistics such as tabulation, measure of central tendency, percentage. A one sample t-test was conducted to determine the significance of the difference between the water use during the pre- and post-COVID-19 lockdown periods.

\section{Results and Discussion}

\section{Analysis of Some characteristics of the Schools investigated in the survey}

Table 1 shows the response of the selected schools to some of the questions inquired from them respectively. The results revealed that the dominant method of hand washing is prevalent in both public and private schools with $95 \%$ and $100 \%$ in both public and private schools respectively. Also, both categories of schools claimed to have sufficient water, though $25 \%$ of the public schools claimed sourcing water from their neighbourhoods to ensure water availability for hand washing within their premises on daily basis. Probably, this challenge could have prompted water rationing among the $80 \%$ of the public schools involved in the survey. Also, both categories of the schools affirmed the increase in water use within their respective schools with $80 \%$ of public and $100 \%$ of the private. Similar observation of increased water use prompted by the novel COVID-19 disease spread was made by Nemati (2015) in in residential areas in California. In the same vein, Lüdtke et al., (2021) attributed the daily increase in daily water use to the behavioural change as a result of the prevalence of COVID-19 disease. In addition, none of the schools claimed having any crises as a result upsurge in water demand for hand-washing to curtail the spread of COVID-19 disease. However, all the schools involved in the investigation obtain water from ground sources such as dug-out wells or deep boreholes mostly probably because of the erratic water supply from the pipe-borne water network. Only $25 \%$ of the private schools claimed to source water from pipe-borne network.

Table 1: Descriptive Analysis of the responses of both Public and Private Schools in the survey.

\begin{tabular}{|c|c|c|c|c|c|c|c|}
\hline \multirow{2}{*}{$\begin{array}{l}\mathbf{S} / \\
\mathbf{N}\end{array}$} & \multirow[t]{2}{*}{ Water Use Variables } & \multicolumn{3}{|c|}{ Public Schools' Response } & \multicolumn{3}{|c|}{ Private Schools' Response } \\
\hline & & $\begin{array}{l}\text { Number } \\
\text { Agreed }\end{array}$ & $\begin{array}{l}\text { Number } \\
\text { Disagreed }\end{array}$ & $\begin{array}{l}\text { No } \\
\text { response }\end{array}$ & $\begin{array}{l}\text { Number } \\
\text { Agreed }\end{array}$ & $\begin{array}{l}\text { Number } \\
\text { Disagreed }\end{array}$ & $\begin{array}{l}\text { No } \\
\text { response }\end{array}$ \\
\hline 1. & $\begin{array}{l}\text { Water provision for Hand } \\
\text { washing }\end{array}$ & 05 & 0 & 01 & 04 & 0 & 0 \\
\hline 2. & Use of water Only & 05 & 01 & 0 & 04 & 0 & 0 \\
\hline 3. & $\begin{array}{l}\text { Sufficiency of water in the } \\
\text { premise }\end{array}$ & 05 & 0 & 01 & 04 & 0 & 0 \\
\hline 4. & $\begin{array}{lll}\text { Source of water from } \\
\text { Neighbourhood }\end{array}$ & 04 & 02 & 0 & 04 & 0 & 0 \\
\hline 5. & C-19 Increases Water Use & 05 & 01 & 0 & 04 & 0 & 0 \\
\hline 6. & Water Scarcity crisis occurrence & 06 & 0 & 0 & 03 & 01 & 0 \\
\hline 7. & Source water from Surface & 02 & 04 & 0 & 04 & 0 & 0 \\
\hline 8. & Water rationing on daily basis & 02 & 04 & 0 & 04 & 0 & 0 \\
\hline 9. & Manual Hand Washing Only & 06 & 0 & 0 & 04 & 0 & 0 \\
\hline 10. & Both auto and manual Hand wash & 02 & 04 & 0 & 03 & 01 & 0 \\
\hline 11. & Ground source of water & 04 & 02 & 0 & 02 & 02 & 0 \\
\hline 12. & Pipe-Borne Water Source & 05 & 01 & 0 & 03 & 01 & 0 \\
\hline 13. & Purchase of water from vendors & 06 & 0 & 0 & 04 & 0 & 0 \\
\hline
\end{tabular}




\section{Perimeter Characteristics of the Schools investigated}

The results in Table 2 shows the characteristics of all public and private schools investigated, Only 2 $(25 \%)$ of them have perimeter fence while $8(75 \%)$ had no perimeter fence. However, all the $7(100 \%)$ of the private schools investigated had perimeter fence. In all of the schools investigated, $60 \%$ were closed up with fence made of cement blocks while $40 \%$ were without fence. The importance of fencing cannot be overlooked as it helps in restricting movement of people, especially across the school premises, and so, helps to control movements in and out. It is expected that a fenceless school has the potential of neighborhood and passersby encroachment in an out of the school, thereby rendering the use of water for hand washing in COVID-19 protocol ineffective. Domestic animals, birds and the like could pollute the prepared water in the open containers if not causing total spill away of the water. However, the fenced schools have the tendency to help in the preservation of water for its effective and timely use, just as found in private schools investigated. Apart from this, the control of the use of the water for the purpose it meant may not be optimally realized in an unfenced territory. Every side of the school becomes a pathway for any passersby, COVID-19 carrier or not. Reverse is the case in fenced institutions where movement of people are easily checked and controlled and so, there is efficient use of water and wash of hands. Eme and Anthony (2011) and Atanda (2013) had revealed the necessity of fence in schools to ensure the safety of students and staff and the encroachment of elements that may pose threat to the security of live and property. However, it is not surprising that all private schools investigated are fenced. The reason for this could be one or the combination of the following:

One, private schools are often limited in land acquisition for development, so the land acquired could be easily fenced at least to prevent it from illegal encroachment and grabbers. Two, private school owners are always conscious of their business territory and always want to showcase their worth in their business to safeguard both students and staff within their care (Nwogu, 2015). Last but not the least is that fencing is a way of beautifying the school premises and its territory. Private schools are quite aware of this and so they try to utilize this within their limited and, at times, closed resources (Hanover Research, 2013). The bottom line is that fencing school has the potential to contribute to the prevention of the spread of COVID-19 disease unlike the unfenced ones.

Table 2: Availability of Fence in the schools

\begin{tabular}{|c|c|c|c|c|c|}
\hline S/No & \multirow{2}{*}{ Ownership } & \multicolumn{2}{|c|}{$\begin{array}{c}\text { Presence of Perimeter } \\
\text { Fenced }\end{array}$} & \multicolumn{2}{c|}{$\begin{array}{c}\text { Absence of } \\
\text { Perimeter Fence }\end{array}$} \\
\cline { 3 - 6 } & & No & $\mathbf{\%}$ & No & $\%$ \\
\hline 1. & Public & 2 & 25 & 6 & 75 \\
\hline 2. & Private & 7 & 100 & 0 & 0 \\
\hline & Total & $\mathbf{9}$ & $\mathbf{6 0}$ & $\mathbf{6}$ & $\mathbf{4 0}$ \\
\hline
\end{tabular}

\section{Pre- and Post-COVID-19 Water Use Pattern among the selected Schools}

Table 3 and Figure 2 presented water use by public and private schools in the investigation. The result showed that there is marked difference in the water use before and after COVID-19 disease came on board. The following observations were made from the survey conducted: Firstly, public and private schools cannot say specifically the quantity of water often used in the pre-COVID-19 era. However, they can estimate what volume they are (using containers of 5litres and 25litres as appropriate for their standard) as a result of the COVID-19 protocol put in place by the government. The Table revealed that the increase is higher in private schools than in public schools with PVI and PV recording the highest percentages in all schools investigated with $80 \%$ and $75 \%$ respectively. However, two schools, PBV and PBVII recorded the highest percentage increase in water use during the post-COVID-19 lockdown era with $75 \%$ and $73.3 \%$ respectively. Though all schools investigated recorded percentage increase in water 
use during the post-COVID-19 lockdown era, there is wide difference in the quantity. For instance, though PBV had $75 \%$ increase with pre- value of 15 litres and post- value of 60litres, compared with PV $\mathrm{V}$ that has 50litres and 200litres in the pre- and post- era respectively, thus given 150litres difference. Generally the volume of water used in the PVs are high when compare with what is obtainable in PBs. Such disparities could be attributed to the business mind in private school owners where everything must be done to keep their schools moving while the government schools are managed with little sense of commitment as work-or-no-work- the- salary-will-be-paid-at-the-end-of-the-month syndrome characterized the public school management in most developing nations, Nigeria inclusive.

Table 3: Pre- and Post- COVID-19 Water Use and source in the selected schools

\begin{tabular}{|c|c|c|c|c|c|c|}
\hline \multirow[t]{2}{*}{ S/No } & \multirow[t]{2}{*}{ School Label } & \multirow{2}{*}{\begin{tabular}{lr}
\multicolumn{2}{l}{ Pre-COVID-19 } \\
Daily & Water \\
Use & (A) $\quad$ (in \\
litres) &
\end{tabular}} & Post-COVID-19 & \multirow{2}{*}{$\begin{array}{l}\text { Difference } \\
\text { Between (a) } \\
\text { and (B) (in } \\
\text { litres) }\end{array}$} & \multirow{2}{*}{$\begin{array}{l}\text { \% Change } \\
\text { in Water } \\
\text { Use }\end{array}$} & \multirow{2}{*}{$\begin{array}{l}\text { Major } \\
\text { Source of } \\
\text { water }\end{array}$} \\
\hline & & & $\begin{array}{llr}\text { Daily } & \text { Water } \\
\text { Use } & \text { (B) } & \text { (in } \\
\text { litres) } & & \end{array}$ & & & \\
\hline 1. & PB 1 & 30 & 60 & 30 & 50 & Ground \\
\hline 2. & PB II & 25 & 50 & 25 & 50 & Ground \\
\hline 3. & PB III & 20 & 50 & 30 & 60 & Ground \\
\hline 4. & PB IV & 25 & 75 & 50 & 66.7 & Ground \\
\hline 5. & PB V & 15 & 60 & 45 & 75 & Ground \\
\hline 6. & PB VI & 35 & 75 & 40 & 46.7 & Ground \\
\hline 7. & PB VI & 20 & 75 & 55 & 73.3 & Ground \\
\hline 8. & PB VII & 25 & 100 & 75 & 75 & Ground \\
\hline 9. & PV I & 50 & 150 & 100 & 66.7 & Ground \\
\hline 10. & PVII & 45 & 150 & 105 & 70 & Ground \\
\hline 11. & PV III & 40 & 125 & 85 & 68 & Ground \\
\hline 12. & PV IV & 35 & 100 & 65 & 65 & Ground \\
\hline 13. & $\mathrm{PV} \mathrm{V}$ & 50 & 200 & 150 & 75 & Ground \\
\hline 14. & PV VI & 50 & 250 & 200 & 80 & Ground \\
\hline 15 & PV VII & 75 & 250 & 175 & 70 & Ground \\
\hline
\end{tabular}

\section{Key: PB: Public Schools $\quad$ PV: Private Schools}

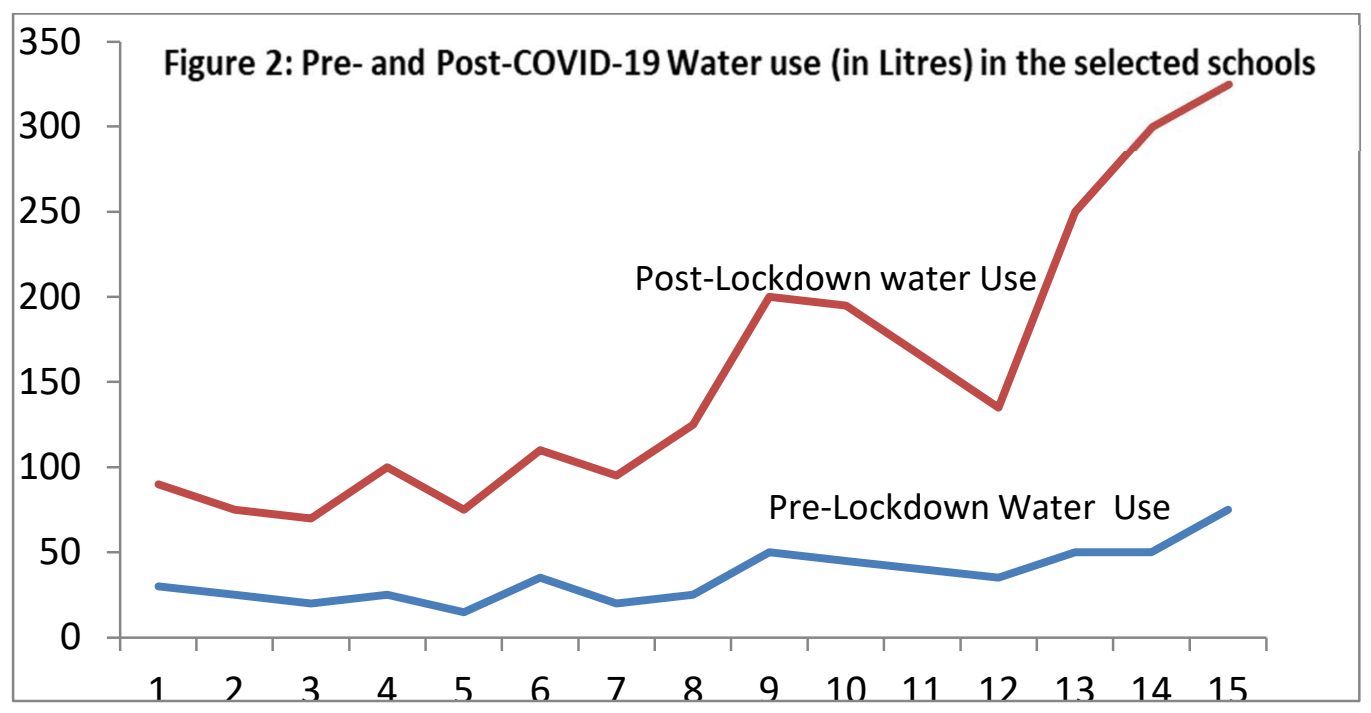

IV. Statistical Test on the difference between Pre- and Post-COVID-19 water use 
In furtherance to ascertain the level of significance of the difference in water use between the two periods, a t-test was conducted. The result as presented in Table 4 showed that there was a highly significant $(\mathrm{p}<0.01)$ difference in the volume of water used by the institutions in the two periods. This implies that water used in the post-COVID-19 lockdown period was significantly higher than water used during the pre-COVID-19 lockdown period. The report of Quintuna and Marcelo (2020) also corroborated this finding. Thus, there is urgent need to ensure an all-time reliable pipe-borne water source to cater for the deficit rather than depending on ground source which is season-dependent for its good yields in the study area to ensure the effectiveness of hand-washing to curtail the spread of COVID-19 disease

Table 4: One-Sample t-Test

\begin{tabular}{|c|c|c|c|c|c|c|}
\hline & \multicolumn{6}{|c|}{ Test Value $=0$} \\
\hline & \multirow[b]{2}{*}{$\mathrm{t}$} & \multirow[b]{2}{*}{ Df } & \multirow[b]{2}{*}{ Sig. (2-tailed) } & \multirow[b]{2}{*}{ Mean Difference } & \multicolumn{2}{|c|}{$\begin{array}{l}99 \% \text { Confidence Interval of the } \\
\text { Difference }\end{array}$} \\
\hline & & & & & Lower & Upper \\
\hline Pre-Lockdown & 8.744 & 14 & .000 & 36.00000 & 23.7434 & 48.2566 \\
\hline Post-lockdown & 6.664 & 14 & .000 & 118.00000 & 65.2902 & 170.7098 \\
\hline
\end{tabular}

Source: SPSS software

\section{Conclusion and Recommendation}

An investigation into the differential water use pattern among fifteen selected post-primary secondary schools in Iwo, Osun State, Nigeria was conducted. The study revealed that there is significant difference between water use during the pre-COVID-19 and post-COVID-19 lockdown era. The result indicated that there is significant increase in water use during the post-COVID-19 era which was partly attributed to COVID-19 protocol which included the provision of clean water for the purpose of hand-washing. The execution of this directive which was enforced by the government had contributed to the increased use of water which was the common preference to the use of hand sanitizer. It was also discovered that private schools use more water than public schools. This could be attributed to the belief of the private school owners that it is their business that should be given adequate attention before their respective public that patronize them. Public schools belong to the government that determines their affairs. It was also discovered the major water use in both private and public schools is ground source. This presupposes that pipe-borne network is not accessible to most of the schools involved in the investigation. It is therefore recommended that all stakeholders, especially the government need to provide other all-time reliable source of water to cater for the additional water use incurred as a result of mitigating the spread of COVID-19 disease. All hands should be on deck to develop pipe-borne network which can run all through the seasons than relying on ground source whose yield is season-dependent.

\section{References}

Atanda, A.I. (2013) Security challenges and effective schooling in Nigeria: Need for school safety precautions by school administration. Nigeria J. Education Administration and Planning (NJEAP), 13(1):55-69

Egbinola, C.N. and Amanambu, A.C., 2015: Water supply, sanitation and hygiene education in secondary schools in Ibadan, Nigeria. In: Szymańska, D. and Środa-Murawska, S. editors, Bulletin of 
Geography. Socio-economic Series, No. 29, Toruń: Nicolaus Copernicus University, pp. 31-46. DOI: http://dx.doi.org/10.1515/bog-2015-0023

Hanover Research (2013) School Fencing: Benefits and disadvantage. Washington D.C.. www.hanoverresearch.com

Ludtko, D.U., Luetkemeier, R., Schneemann, M. and Liehr, S. (2021) Increase in daily household water demand during the first wave of the COVID-19 Pandemic in Germany. Water, 2021, 13, 260: https://doi.org/10.3390/w13030260.

Nemati, M. (2020) COVID-19 and urban water consumption. ARE Update, 24(1):9-11. University of California Giannini Foundation of Agricultural Economics.

Nunes, L.G.C.F., Soares, A.E.P, Soares, W.I. and da Silva, S.R. (2019) Water consumption in public schools: a case study. J. Water, Sanitation and Hygiene for Development, 9.1.: 119-128 doi: 10.2166/washdev.2019.074

Nwogu, G.A.I. (2015) Barriers to equality of access to educational opportunity in Nigeria: A Philosophical Perspective. J. Education and Practice, 6(4): 148-152.

Ogunbode, T.O., Nejo Y.T. and Kehinde, O. J. (2020) COVID-19 Pandemic/Lockdown and its Impact on sustainable access to safe water in the developing world: A Case Study. European J. Basic Medical Sciences, 10(2):1-10.

Quintuña, J. and Marcelo, D. (2020) Estimated Impact of COVID-19 on Water Needs and Volume and Quality of Wastewater (July 15, 2020). Available at SSRN: https://ssrn.com/abstract=3651551 or http://dx.doi.org/10.2139/ssrn.3651551 